\title{
AN UPDATED LIST OF THE SCALE INSECT (HEMIPTERA COCCOMORPHA) FAUNA OF SOME SICILIAN ENDEMIC PLANTS $\left({ }^{1}\right)$
}

\author{
(*) Dipartimento di Agricoltura, Alimentazione e Ambiente (Di3A), University of Catania, Via S. Sofia, 100. 95123 \\ Catania, Italy; corresponding Author: gamazzeo@unict.it
}

\begin{abstract}
Mazzeo G., Nucifora S., Russo A., Suma P., Longo S. - An updated list of the scale insect (Hemiptera Coccomorpha) fauna of some Sicilian endemic plants.

In this study Authors report scale insects (Hemiptera: Coccomorpha) species for the first time recorded on some endemic plants of Sicilian flora, namely, Abies nebrodensis Mattei (Pinaceae), Astragalus siculus Biv. (Leguminosae), Betula aetnensis Rafinesque (Betulaceae) and Zelkova sicula Di Pasquale Garfi \& Quezel (Ulmaceae).

Abies nebrodensis is present in a single small population on Madonie Mountains. On this conifer the fir scale Parlatoria parlatoriae (Šulc) (Diaspididae) was collected. On B. aetnensis, that colonizes the lava substrates of Etna Volcano mainly at 1300-1900 m.a.s.l., a consistent population of an undescribed Diaspidiotus species (currently being described) was collected. Moreover Lepidosaphes ulmi (Linnaeus) (Diaspididae) was detected and collected on A. siculus which is characteristic plant of the upper part of the volcano. Zelkova sicula is a very rare relict of the Tertiary, belonging to a genus of plants already extinct in Continental Europe; with only two small populations living in restricted woodland areas in south oriental Sicily where two scale insects were collected: Aspidiotus nerii (Costa) (Diaspididae) and Parthenolecanium sp. (Coccidae).
\end{abstract}

Key Words: Mount Etna, Madonie Mountains, Mount Iblei massif, Diaspididae, Coccidae.

\section{INTRODUCTION}

From a zoogeographic point of view, the particular position of Sicily in the middle of the Mediterranean basin, together with its paleoclimatic and paleogeographic events gave to the island an important role to its territorial species distribution.

The island can be considered to be a refuge for species that did not re-colonize the Italian peninsula after ice age and this process has led to the genetic uniqueness of many Sicilian species. As a consequence of the paleogeographic connections with the surrounding lands that were allowed repeated biocenotic exchanges in ancient times, today Sicily is considered one of the most relevant biodiversity hotspots in the Mediterranean area (MASSA et al., 2011), as it can be deduct from the richness in plant species. In the island, there are about 3,000 species of plants and more than 300 endemic taxa (BRULlo et al., 1995; BAIAMONTE et al., 2015; Domina et al., 2012).

Sicily represents a place of great interest for the study of plants and animals, particularly for insects. Scale insects (Hemiptera: Coccomorpha), among them, are the most interesting one due to the close connections with their host plants which they do not leave at all or almost at all for the duration of their life (MAZZEO et al., 2011). In Sicily there are 169 species of scale insects, which represent $42 \%$ of the Italian scale insects fauna. The species mostly belong to the families Diaspididae (43\%), Pseudococcidae (20\%) and Coccidae (17) (MAZzeo et al., 2011).

\footnotetext{
${ }^{1}$ Original scientific contribution presented and discussed at XIV International Symposium on Scale Insect Studies, Catania-Italy, 13-16 June 2016.
}

Several places on the island have the highest relevance and have been established as protected areas. Some of the most relevant ones are in the Central, North and Eastern sides. In some of these areas we have carried out our research with the purpose of increasing the knowledge on scale insects living on the endemic plants.

\section{MATERIAL AND METHODS}

The surveys have been carried out in the last years (from 2005 to present) in Sicilian areas of particular ecological interest, selected on the basis of the presence of endemic plants. The preliminary observations have interested three sites and five plants species as thereafter described. In each site, samples were collected from infested plants and the specimens of scale insects collected, in laboratory were preserved in $80 \%$ alcohol. Adult females were slidemounted using the method given by WILLIAMS \& WATSON (1988), examined using a compound microscope and identified using keys available in the literature (BALACHOWSKY, 1951, 1954; KosZTARAB \& KOZÁR, 1988; WILLIAMS \& WATSON, 1988; HODGSON, 1994). The reference specimens were deposited in the collection of Department of Agriculture, Food and Environment (Di3A).

\section{THE SITES}

The first survey was conducted in the Madonie Mountains; they represent the terminal portion of the Apennine mountain range, situated in the Central Northern part of Sicily, characterized by a high diversity of landscapes. More than 1,700 plant taxa occur in the Madonie Mountains with over $20 \%$ are endemisms, including Abies nebrodensis Mattei (Pinaceae) (BAIAMONTE et al., 2015). 
The second place has been identified on the Mount Etna; located in Eastern Sicily, it is the highest active volcano in Europe. Originated from the overlapping of several volcanic structures formed at different times, it is subject to constant changing in its morphology (Cocuzza Silvestri \& RonsisvalLE, 1990). A large area of the volcano is covered by the Etna Regional Park that was established in 1987 to safeguard unique natural landscapes. In 2013, Mount Etna, was inscribed as a UNESCO World Heritage Site. In this site, endemic plants like Astragalus siculus Biv. (Fabaceae) and Betula aetnensis Rafinesque (Betulaceae) are present.

The last site Iblei Mountains, situated in the SouthEastern part of the island, have been surveyed. They are mainly composed of Miocene limestones that often form large boards eroded by numerous river valleys (QUEZEL et al., 1993). In a particular area, that consists geologically of an extensive system of volcanic and calcareous sedimentary deposits, the endemic plant Zelkova sicula Di Pasquale Garfi \& Quezel (Ulmaceae) grows.

\section{THE ENDEMIC PLANTS}

\section{Abies nebrodensis}

The Sicilian fir grows in a large valley in the north slopes of Mount Scalone along a steep and stony terrain, at around $1500 \mathrm{~m}$ a.s.l. The tree can reach $15 \mathrm{~m}$ in height and has short dark green needles that persist during the entire year. At first it was thought that this species was variety of $A$. alba Mill. but later it was established as a new species in the 50's. It has been depleted by overexploitation over time and nowadays it consists of a very fragmented relict population with 30 very old trees covering an area of less than $1.5 \mathrm{~km}^{2}$. It has been categorized as "Critically Endangered" according to IUCN Red List (MONTMOLLIN \& STRAHM, 2005).

\section{Betula aetnensis}

Betula aetnensis is endemic to Sicily and only grows on Mount Etna, in the damp low ground between 1300 and 2100 m.a.s.l. It is a pioneer plant preparatory of mature wooded formations and it stands together with Pinus laricio Poiret, Fagus sylvatica Linnaeus and Astragalus siculus (Plini \& Tondi, 1989) which keeps growing to the highest points of the volcano.

Two populations are present inside the Etna Regional Park in two areas of about $0.25 \mathrm{~km}^{2}$ and $4 \mathrm{~km}^{2}$, on the western and the north-eastern slopes (STRANO, 2010), characterized by a mountainous microclimate with a deep and long-lasting snow cover (LEONARDI et al., 1994).

The species has been considered for a long time to be a subspecies of $B$. pendula Roth which is present in some other Italian regions with the southern limit of distribution being in Campania and the superior one in the North Europe (Strano, 2010). During the last ice age, South Italy and Sicily have accounted for Betula a refuge area. In the postglacial period it has remained confined to Mount Etna where it found favorable conditions of life that allowed for the differentiation of a new species of Betula through genetic isolation.

Even if the species is present in large populations, and it is characterized by the asexual reproduction in the wooded areas, its renovation only seems possible in areas untouched by human activities and natural events.

\section{Astragalus siculus}

The species grows at about 1600-2450 m.a.s.l. on Mount Etna, characterized by a very poor endemic community of pioneer species. It is so common that it is considered the most characteristic species of the high mountain landscape (PoLI, 1991). This plant is an endemic thorny species that forms great cushions of about 1-2 $\mathrm{m}$ in diameter. It is characterized by roots that hold volcanic sands in place and stems with robust apical thorny leaves, that protect other delicate seedlings like violet, anthemis, etc.. Astragalus siculus frequently enters into various types of forests such as in those of birch trees.

\section{Zelkova sicula}

The Sicilian Zelkova has been discovered in the 90's in two sites only, both on the northern slopes of the Iblei Mountains; precisely the site of the first record in the SIC "Bosco Pisano" (Buccheri) of about 0.4 ha and another one, more recently recorded, of about 0.8 ha, in the same mountain massif (SIC "Cozzo Ogliastri”, Melilli). In these two sites, 230 and 1,200 specimens have been counted, respectively.

The plant is a bush, usually $2-3 \mathrm{~m}$ high. Reproduction is agamic, performed due to root suckers, and individuals produced in this manner are genetically identical to the original plant. The pronounced dry periods during summer can lead to the withering of branches or of entire individuals, but they are able to make a second regrowth before the autumn (GARFÌ \& BUORD, 2012).

Zelkova sicula belongs to a genus which is extinct in continental Europe, that comprises of a small number of species, mostly growing in Western and Eastern Asia, except the two in the Mediterranean basin, i.e. Z. sicula in Sicily and Z. abelicea in Crete (FINESCHI et al., 2004). Both species represent relicts and are endangered due to habitat change.

This species has been classified as "Critically Endangered" according to the IUCN Red List because the areas in which this species is found are very small, and both the areas as well as the number of individuals seems to continue to decline (Montmollin \& Strahm, 2005). From 2011 it has been the object of a conservation project.

\section{RESULTS}

\section{SPECIES OF SCALE INSECTS RECORDED ON ENDEMIC PLANTS}

\section{Abies nebrodensis}

Four species of scale insects have been reported on this plant until now (GARcía Morales et al., 2016): Dynaspidiotus abietis (Schrank) (Diaspididae), Nemolecanium graniforme (Wunn), Eulecanium sericeum (Lindinger) and Physokermes hemicryphus (Dalman) (Coccidae).

- Dynaspidiotus abietis, the hemlock scale, harmful to conifers in Central Europe, has been also known for Abies alba, A. cephalonica Loud. and $A$. nordmanniana (Steven) Spach, and other conifers. It can be harmful to ornamental plants in urban areas. Recorded in Sicily, it is also present all over Italy (MAROtTA \& Russo, 1992).

- Nemolecanium graniforme. This rare species is only present in 7 European countries and always associated with host plants belonging to the family Pinaceae and the genus Abies. Recorded on A. alba and A. cephalonica, it has been found in Sicily on A. nebrodensis in 1985 (Covassi \& BINAZZI, 1985).

- Eulecanium sericeum. Recorded on A. alba by LINDINGER (1912) it is listed in Scalenet as living also on Abies nebrodensis. The species is included in the Italian Scale 
insect fauna where it is known only to be found in Northern Italy. There is no evidence of its presence in Sicily and on A. nebrodensis.

- Physokermes hemicryphus (Coccidae) is known for Picea spp., A. alba in some European countries, Italy included, where it has been also recorded on Picea excelsa and P. pungens. There is no evidence of its presence in Sicily neither on A. nebrodensis.

With regard to these two latter species, a misunderstanding could have occurred about the ecological association with $A$. nebrodensis due to its uncertain taxonomic position and to the fact that the plant had been considered to be a variety of $A$. alba before the establishment of the new species. These two cases represent an update in the scale insect species reported for $A$. nebrodensis.

Our surveys on $A$. nebrodensis led to the discovery of the armored scale Parlatoria parlatoriae (Šulc).

It has been recorded in Sicily in Mount Scalone, Madonie's Park infesting the needles of plants. The species is listed among the scale insects that infest fir trees in Europe and has been associated with Abies, Cedrus and other conifers (GARCía Morales et al., 2016). This turanic-European species (LONGO et al., 1999) is rare and has been recorded in Northern Italy on Pinus nigra (Pellizzari, 1976).

This is the first record for Abies nebrodensis (new ecological association) and for Sicily (new places). Specimens examined: 12 females, collected by Nucifora S., 25.XII.2009, on leaf of Abies nebrodensis, Madonie Mountains, Polizzi Generosa (PA).

\section{Betula aetnensis}

Fifty-one scale insect species have been recorded on Betula genus in the world (Table 1) and 17 of them are present in Italy even if on different host plants, with the exception of Chionaspis salicis (Linnaeus) which has been recorded on Betula alba in the Valle d'Aosta Region by Matile Ferrero \& Pellizzari (2002). No species has been recorded until now on Betula aetnensis.

During our surveys, an armored scale has been found on this host. The morphological analysis led us to assign the species to the Diaspidiotus genus. It seems that it does not match with other known species and a detailed analysis is being run in order to define it. This is the first record of a scale insect on Betula aetnensis. Specimens examined, all collected on bark of Betula aetnensis by Nucifora S.: 1 female, 14.VII.2005, Mount Etna, Rifugio Citelli, Sant'Alfio (CT); 5 females, 11.VII.2009, 5 females, 24.VII.2010, 2 females 18.IX.2011, 2 females 23.III.2014, 10 females 08.III.2016, Mount Etna, Mount Baracca, Sant'Alfio (CT).

\section{Astragalus siculus}

Thirty-one scale insects are listed in Scalenet (GARCÍA Morales et al., 2016) in the world on Astragalus genus (Table 2). Ten of these species are present in Italy (5 of which are present in Sicily) even if on other host plants, never on Astragalus.

During our research we found some adult females of the armored scale Lepidosaphes ulmi (Linnaeus) on the branches of the plant.

The oystershell scale is considered as a cosmopolitan species, very common and polyphagous having been found on host plants belonging to many genera in several families (GARCía Morales et al., 2016). It is considered as one of the most serious pests, even though its infestations can be reduced by the action of natural enemies (GARCÍA MORALES et al., 2016).

This is the first record for Astragalus siculus (new ecological association). Specimens examined: 1 female, collected by Nucifora S., 10.VII.2005, on Astragalus siculus Mount Etna, Rifugio Citelli, Sant'Alfio (CT).

\section{Zelkova sicula}

The scales associated with the Zelkova genus are 23 and 6 of these species are present in Italy (GARCÍA MORALES et al., 2016) (Table 3). In Sicily, 5 of them are already present. No scale insect species have been recorded on $Z$. sicula before our study whereas a new species and a new genus of aphids was described in 2002 by BARBAGALlo (2002) on plants growing in "Bosco Pisano".

Our field work on the same site led to the discovery of two scale insect species, i.e. the armoured scale Aspidiotus nerii (Costa) (Diaspididae) and a soft scale.

The oleander scale, a cosmopolitan species, is highly polyphagous. It is considered a pest of crops and ornamental plants. Specimens examined: 3 females, collected by Nucifora S., 25.IX.2015, on leaf of Zelkova sicula, Bosco Pisano, Buccheri (SR).

In this study, the specimens were found on the lower surface of leaves only, where the female scale covers showed an irregular outline, caused by the presence of hairs on the leaf.

With regard to the soft scale, in the course of repeated field work on the twigs of Zelkova, some mature females have been recorded which are characterized by a brown to reddish colour and convex body. Their morphological features seem to lead to the genus Parthenolecanium. Some investigation is necessary to identify the species. Specimens examined collected on Zelkova sicula, Bosco Pisano, Buccheri (SR): 1 female, collected by Campo G., 9.VII.2015, 3 females collected by Longo S., 26.IV.2016.

\section{CONCLUSIVE REMARKS}

The scale insect fauna of Sicilian endemic plants have been scarcely studied and little to no data was available up to now about the species that live on Abies nebrodensis, Betula aetnensis, Astragalus siculus and Zelkova sicula.

The results of this study allowed us to provide an update on the scale insects associated to these plants.

The exclusive relations between scale insects and their host plants are very interesting if the plants are endemic to an area and closely related to the environment where the species was born.

Our study is the first contribution to the knowledge of scale insect fauna on endemic Sicilian plants but the research will continue in order to increase the knowledge on this fascinating topic.

\section{REFERENCES}

Baiamonte G., Domina G., Raimondo F. M., BAzAn G., 2015 - Agricultural landscapes and biodiversity conservation: a case study in Sicily (Italy). - Biodiversity Conservation, 24: 3201-3216.

BALACHOWSKY A.S., 1951 - Les cochenilles de France, d'Europe, du Nord de l'Afrique et du bassin Méditerranéen. VI. - Monographie des Coccoidea; Dia- 
Table 1 - Scale insects species listed on Betula genus plants by Scalenet (GARCÍA MORALES et al., 2016); * species present in Italy.

\begin{tabular}{|c|c|}
\hline FAMILY & SPECIES \\
\hline \multirow{28}{*}{ Diaspididae } & Andaspis betulae (Borchsenius) \\
\hline & Aonidomytilus ceanothi (Ferris) \\
\hline & Chionaspis acericola Hollinger \\
\hline & Chionaspis alnus (Kuwana) \\
\hline & Chionaspis floridensis Takagi \\
\hline & Chionaspis furfura (Fitch) \\
\hline & Chionaspis lintneri Comstock \\
\hline & Chionaspis salicis (Linnaeus)* \\
\hline & Chionaspis triformis Tippins \& Beshear \\
\hline & Comstockaspis perniciosa (Comstock)* \\
\hline & Diaspidiotus ancylus (Putnam) \\
\hline & Diaspidiotus forbesi (Johnson) \\
\hline & Diaspidiotus juglansregiae (Comstock) \\
\hline & Diaspidiotus lenticularis (Lindinger)* \\
\hline & Diaspidiotus osborni (Newell \& Cockerell)* \\
\hline & Diaspidiotus ostreaeformis (Curtis)* \\
\hline & Diaspidiotus pyri (Lichtenstein)* \\
\hline & Diaspidiotus uvae (Comstock)* \\
\hline & Diaspidiotus zonatus (Frauenfeld)* \\
\hline & Lepidosaphes conchiformis (Gmelin)* \\
\hline & Lepidosaphes malicola (Borchsenius) \\
\hline & Lepidosaphes salicina Borchsenius \\
\hline & Lepidosaphes tubulorum (Ferris) \\
\hline & Lepidosaphes ulmi (Linnaeus)* \\
\hline & Lepidosaphes ussuriensis (Borchsenius) \\
\hline & Melanaspis mimosae Comstock \\
\hline & Parlatoreopsis chinensis (Marlatt) \\
\hline & Velataspis dentata (Hoke) \\
\hline \multirow{12}{*}{ Coccidae } & Ceroplastes ceriferus (Fabricius)* \\
\hline & Eulecanium ciliatum (Douglas) \\
\hline & Eulecanium douglasi (Šulc)* \\
\hline & Eulecanium tiliae (Linnaeus)* \\
\hline & Eulecanium transvittatum (Green) \\
\hline & Neopulvinaria innumerabilis betheli King \\
\hline & Neopulvinaria innumerabilis innumerabilis (Rathvon)* \\
\hline & Parthenolecanium corni corni (Bouché)* \\
\hline & Pulvinaria borchsenii Danzig \\
\hline & Pulvinaria kirgisica Borchsenius \\
\hline & Pulvinaria occidentalis (Cockerell) \\
\hline & Pulvinaria vitis (Linnaeus)* \\
\hline Cryptococcidae & Pseudochermes betula (Wu \& Liu) \\
\hline \multirow[t]{2}{*}{ Eriococcidae } & Acanthococcus spiraeae Borchsenius \\
\hline & Dysmicoccus wistariae (Green) \\
\hline \multirow{5}{*}{ Pseudococcidae } & Fonscolombia rotunda (Kanda) \\
\hline & Heliococcus osborni Sanders \\
\hline & Phenacoccus aceris (Signoret)* \\
\hline & Spilococcus nanae Schmutterer \\
\hline & Spilococcus pacificus (Borchsenius) \\
\hline Steingeliidae & Steingelia gorodetskia Nasonov \\
\hline \multirow{2}{*}{ Xylococcidae } & Xylococculus betulae (Pergande in Hubbard \& Pergande) \\
\hline & Xylococcus japonicus Oguma \\
\hline
\end{tabular}


Table 2 - Scale insects species listed on Astragalus genus plants by Scalenet (GARCíA Moraleset al., 2016); * species present in Italy; ${ }^{* *}$ species present in Sicily

\begin{tabular}{|c|c|}
\hline FAMILY & SPECIES \\
\hline Coccidae & $\begin{array}{l}\text { Eulecanium caraganae Borchsenius } \\
\text { Rhizopulvinaria artemisiae (Signoret)* }\end{array}$ \\
\hline Diaspididae & $\begin{array}{l}\text { Contigaspis sarkissiani (Kaussari \& Balachowsky in Balachowsky) } \\
\text { Diaspidiotus baiati (Kaussari) } \\
\text { Diaspidiotus elaeagni (Borchsenius) } \\
\text { Lepidosaphes malicola (Borchsenius) } \\
\text { Melanaspis inopinata (Leonardi)** } \\
\text { Mercetaspis halimodendronis (Borchsenius \& Matesova) } \\
\text { Mercetaspis halli (Green) } \\
\text { Mercetaspis sureyana (Bodenheimer) } \\
\text { Parlatoria oleae (Colvée)** } \\
\text { Targionia haloxyloni Hall }\end{array}$ \\
\hline Eriococcidae & $\begin{array}{l}\text { Anophococcus cingulatus (Kiritchenko) } \\
\text { Rhizococcus astragali Kaydan }\end{array}$ \\
\hline Margarodidae & Porphyrophora epigaea Danzig \\
\hline Orthezidae & Orthezia urticae (Linnaeus) ${ }^{* *}$ \\
\hline Pseudococcidae & $\begin{array}{l}\text { Atrococcus achilleae (Kiritchenko)* } \\
\text { Atrococcus indigens (Borchsenius) } \\
\text { Atrococcus parvulus (Borchsenius) } \\
\text { Erimococcus kimmericus Kiritshenko } \\
\text { Erimococcus montanus (Bazarov \& Babaeva) } \\
\text { Heliococcus astragali Danzig } \\
\text { Heliococcus mirabilis (Bazarov) } \\
\text { Heliococcus montanus Borchsenius } \\
\text { Peliococcus turanicus Kiritshenko* } \\
\text { Pelionella tritubulatus Kiritshenko* } \\
\text { Phenacoccus solani Ferris** } \\
\text { Pseudococcus maritimus Ehrhorn } \\
\text { Trionymus multivorus (Kiritchenko)* } \\
\end{array}$ \\
\hline Putoidae & $\begin{array}{l}\text { Puto superbus (Leonardi)* } \\
\text { Puto yuccae (Coquillett) }\end{array}$ \\
\hline
\end{tabular}

Table 3 - Scale insects species listed on Zelkova genus plants by Scalenet (GARCíA Morales et al., 2016); * species present in Italy; ** species present in Sicily.

\begin{tabular}{|c|c|}
\hline FAMILY & SPECIES \\
\hline Coccidae & $\begin{array}{l}\text { Coccus pseudomagnoliarum (Kuwana)** } \\
\text { Eulecanium cerasorum (Cockerell) } \\
\text { Parasaissetia nigra (Nietner)* } \\
\text { Parthenolecanium glandi (Kuwana) } \\
\text { Pulvinaria horii Kuwana } \\
\text { Pulvinaria nipponica Lindinger } \\
\text { Pulvinaria nishigaharae (Kuwana) } \\
\text { Pulvinaria regalis Canard } \\
\text { Takahashia japonica (Cockerell) }\end{array}$ \\
\hline Diaspididae & $\begin{array}{l}\text { Hemiberlesia lataniae (Signoret)* } \\
\text { Lepidosaphes conchiformis (Gmelin)** } \\
\text { Lepidosaphes granati (Koroneos)** } \\
\text { Lepidosaphes zelkovae Takagi \& Kawai } \\
\text { Lindingaspis setiger (Maskell) } \\
\text { Lopholeucaspis japonica (Cockerell) } \\
\text { Pseudaulacaspis pentagona Targioni Tozzetti** }\end{array}$ \\
\hline Eriococcidae & Acanthococcus abeliceae (Kuwana) \\
\hline Monophlebidae & $\begin{array}{l}\text { Drosicha howardi (Kuwana) } \\
\text { Drosicha maskelli (Cockerell) }\end{array}$ \\
\hline Pseudococcidae & $\begin{array}{l}\text { Dysmicoccus racemus McKenzie } \\
\text { Phenacoccus pergandei Cockerell } \\
\text { Planococcus japonicus Cox }\end{array}$ \\
\hline Rhizoecidae & Ripersiella hibisci Kawai \& Takagi \\
\hline
\end{tabular}


spidinae (Troisième partie) Aspidiotini (fin). Entomologie Appliquée Actualités Scientifiques et Industrielles, 1127: 561-720.

Balachowsky A.S., 1954 - Les cochenilles Paléarctiques de la tribu des Diaspidini. - Memoires Scientifiques de l'Institut Pasteur, Paris, 450 pp.

BARBAGALlo S., 2002 - Zelkovaphis trinacriae, a new Eriosomatine aphid genus and species living on Zelkova in Sicily (Rhynchota: Aphididae). - Boll. Zool. agr. e Bachic., Ser. II, 34 (3): 281-301.

Brullo S., Minissale P., Spampinato G., 1995 Considerazioni fitogeografiche sulla flora della Sicilia. Ecologia Mediterranea, 21 (1/2): 99-117.

Cocuzza Silvestri S., Ronsisvalle G., 1990 - Etna un ritratto del vulcano. Trincale ed., $211 \mathrm{pp}$.

Covassi M., Binazzi A., 1985 - Primi reperti su alcuni fitomizi dell'Abies nebrodensis (Lojac.) Mattei in Sicilia (Homoptera). - Atti XIV Congr. Naz. Ital. Ent., Palermo, Erice, Bagheria, 1985: 81-86.

Domina G., Marino P., Spadaro V., Raimondo F. M., 2012 - Vascular flora evolution in the major Mediterranean islands. - Biodiversity Journal, 3(4): 337-342.

Fineschi S., Cozzolino S., Migliaccio M., Vendramin G. G., 2004 - Genetic variation of relict tree species: the case of Mediterranean Zelkova abelicea (Lam.) Boisser and Z. sicula Di Pasquale, Garfi and Quézel (Ulmaceae). - Forest Ecology and Management, 197: 273-278.

García Morales M., Denno B.D., Miller D.R., Miller G.L., Ben-Dov Y., Hardy N.B., 2016 - ScaleNet: A literature-based model of scale insect biology and systematics. Database. doi: 10.1093/database/bav118. http://scalenet.info.

GARFì G., BUORD S., 2012 - Relict species and the challenges for conservation: the emblematic case of Zelkova sicula Di Pasquale, Garfi et Quézel and the efforts to save it from extinction. - Biodiversity Journal, 3 (4): 281-296.

KosztARAB M. KozÁR, F., 1988 - Scale Insects of Central Europe. Akademiai Kiado, Budapest, 456 pp.

HodGson C.J., 1994 - The scale insect family Coccidae: an identification manual to genera. - Boletin del Museo de Entomologia de la Universidad del Valle, CAB International Wallingford, Oxon, UK, 639 pp.

LeOnardi S., Rapp M., Failla M., Komaromy E., 1994 Organic matter and nutrient cycling within an endemic birch stand in the Etna massif (Sicily): Betula aetnensis Rafin. - Vegetatio, 111: 45-57.

LINDINGER L., 1912 - Die Schildläuse (Coccidae) Europas,
Nordafrikas und Vorder-Asiens, einschliesslich der Azoren, der Kanaren und Madeiras. Ulmer Stuttgart, 388 pp.

Longo S., Marotta S., Pellizzari G., Russo A., TRANFAgLia A., 1999 - A zoogeographical analysis of the Italian scale insect fauna. - Boll. Zool. Agr. Bachic., Ser. II, 31(2): 139-151.

Marotta S., Russo A., 1992 - Note faunistiche sulla coccidofauna (Homoptera Coccoidea) delle abetine nell'Appennino calabro-lucano. - Atti del Convegno "Le avversità delle abetine in Italia". Vallombrosa (FI), 25-26 giugno 1992: 189-196.

Massa B., Sbordoni V., Vigna Taglianti A., 2011 - La Biogeografia della Sicilia: considerazioni conclusive sul XXXVII Congresso della Società Italiana di Biogeografia. - Biogeographia, 30: 685-694.

Matile Ferrero D., Pellizzari G., 2002 - Contribution to the knowledge of the scale insects (Hemiptera Coccoidea) from the Aosta Valley (Italy). - Bollettino di Zoologia Agraria e di Bachicoltura (Milano), 34 (3): 347-360.

Mazzeo G., Russo A., Suma P., 2011 - Considerazioni biogeografiche sulla coccidofauna della Sicilia. Biogeographia, 30: 491-501.

Montmollin B. De, Strahm W. (Eds). 2005 - The Top 50 Mediterranean Island Plants: Wild plants at the brink of extinction, and what is needed to save them. - IUCN/SSC Mediterranean Islands Plant Specialist Group. IUCN, Gland, Switzerland and Cambridge, UK. X+110 pp.

Pellizzari G., 1976 - Osservazioni sulla Syngenaspis parlatoriae Sulc e su altre cocciniglie infeudate alle conifere. - Bollettino di Zoologia Agraria e di Bachicoltura (Milano) Ser. II, 13: 1-21.

Plini P., Tondi G., 1989 - La distribuzione appenninica della Betulla Bianca. - Natura e Montagna, 36 (3-4): 2128.

Poli E., 1991 - Piante e fiori dell'Etna. Edizioni Sellerio, Palermo 200 pp..

Quezel P., Di Pasquale G., Garfi G., 1993 - Découverte d'un Zelkova en Sicilie sud-orientale. Incidences biogéographiques et historiques. - C.R. Acad. Sci. Paris, t. 316, Série III: 21-26.

StRANO F., 2010 - Betula aetnensis Raf. nel Parco Naturale dell'Etna: analisi vegetazionale ed ecologica. Dottorato di ricerca in biologia ed ecologia vegetale in ambiente mediterraneo - XXIII Ciclo. Available on line: http://hdl.handle.net/10761/135.

Williams, D.J. Watson, G.W., 1988 - The Scale Insects of the Tropical South Pacific Region. Pt. 1. The Armoured Scales (Diaspididae). CAB International Wallingford, U.K., 290 pp. 